\title{
US Espionage against Poland in 1970-1989
}

\begin{abstract}
The objective scope of the research problem presented in the text covers a selection of issues concerned with the US espionage against Poland in the period between 1970 and 1989. The main goal of the text is to present the Polish intelligence services' state of knowledge and habits of mind concerned with the threats springing from the US spying activity. In order to elaborate the research problem, the following research questions have been presented: (1) What was the scope of the recognition of the US espionage by the Polish intelligence services in the period of 1970-1989?, (2) What areas of interest in the US espionage against Poland were predominant in the period of 1970-1989?

The text focuses on: (1) an overall description of espionage in Poland (allowing for both the quantitative aspects of the phenomenon and the legal aspects), (2) areas of interest for the US intelligence in Poland (taking into account both the activity of US diplomatic posts and some selected spheres of interest to the US intelligence services, e.g. economy, industry and academia).

The text uses material and documentation generated by the Ministry of the Interior and the Ministry of Defence (including subordinate institutions, e.g. special services) in the years 1970-1989. The theory of speech acts by J. L. Austin has been liberally used to critically analyse the material and documentation. Besides, a dogmatic interpretation of the law has been used to analyse the legal issues of espionage.
\end{abstract}

Key words: espionage, spying activity, intelligence, counter-intelligence, US espionage, intelligence services, state security, information security

\section{Introduction}

$\mathbf{T}$ he material scope of the analysis presented in the text includes the issues concerned with espionage against Poland engaged in by the US in 1970-1989. The timespan is, on the one hand, associated with the entry into force of the new regulations penalising the crime of espionage in Poland (1970), while on the other hand it is related to the beginning of Poland's political transformation (1989). The text focuses on the issues concerned with: (1) a quantitative description of espionage against Poland (including US activities), (2) legal aspects of the fighting of espionage in Poland. Also, issues concerned with areas of interest for the US espionage in Poland have been taken into account, and in particular: (1) the activity of US diplomatic and consular posts, (2) relations of US diplomatic and consular representatives with the Polish opposition and Church, (3) the threat of espionage infiltrating the fields of economy and industry, (4) the threat of espionage infiltrating the field of academia.

The main goal of the text is to present the degree of the recognition of the threat of espionage from the US by the Polish counter-intelligence and intelligence services. In this scope, the analysis will constitute an attempt at reconstructing the Polish intelligence services' knowledge and habits of mind concerned with the US espionage against Po- 
land, which is not necessarily connected with any real threat of espionage, but may serve to portray the perception of such threats. In order to elaborate the material scope of the analysis of the problem of espionage, the text features the following research questions: (1) What was the scope of the recognition of the US espionage by the Polish intelligence services in the period of 1970-1989?, (2) What areas of interest in the US espionage against Poland were predominant in the period of 1970-1989?

In the period of 1970-1989 a large number of papers on espionage were written at graduation seminars held at schools run by the Ministry of the Interior and the Ministry of National Defence. However, these works were not in common use, and their accessibility was subject to restrictions on account of a variety of state secrecy clauses appended thereto. The practice of appending various secrecy clauses to graduation theses followed mainly from the special kind of subject matter and the use by officers of law-enforcement agencies of the material on on-going or concluded proceedings concerned with intelligence and counter-intelligence activities.

The main monographs, especially in the scope of the penal and substantive aspects of espionage in the period in question, include a paper by S. Hoc entitled Issues of criminal responsibility for espionage, which was based on his earlier habilitation dissertation defended at the Academy of Internal Affairs (Hoc, 1985). Another noteworthy monograph addressing the penal and substantive issues was a paper by S. Pikulski entitled A crime of espionage in theory and practice (Pikulski, 1987). A distinctive characteristic of these papers was the fact that the publisher was the ministry-related Academy of Internal Affairs or the very Ministry of the Interior, and that they were for internal use only. A paper entitled Espionage, intelligence, articles by Polish counter-intelligence colonel J. Bronisławski was a publication made available for public use; it was published by the Ministry of National Defence. J. Bronisławski's publication drew on some of the content included in the author's doctoral dissertation entitled Espionage, intelligence and sabotage in the Polish criminal law (1772-1960). Compared with the papers by authors mentioned above (Bronisławski, 1974), it was to a lesser extent that it stressed the current penal and substantive aspects in the light of the Polish law. Psychological motivation for espionage by W. Białowąs was an interesting work in the sense that the description of espionage issues was coupled with psychological concepts of human behaviour determinants. Since the publication drew on the information concerned with espionage motivation and based on source material coming from, inter alia, the Chief Military Prosecutor Office, it obtained a secrecy clause. The publisher of W. Białowąs's monograph was the Department of Professional Training at the Ministry of the Interior (Białowąs, 1980). As regards the crime of "treason against the native country," of note is the monograph by J. Wojciechowska entitled Treason against the native country in the Polish criminal law in comparative light (Wojciechowska, 1975).

\section{Methodology}

As for the quantitative description of espionage in Poland, use has been made of the Ministry of the Interior (Office "C") data, which were developed in 1986 (A Catalogue..., 1986). These data are of a comprehensive character, that is they include information on 
the number of convictions and spying operations for the benefit of individual foreign states or other entities. Even though the available data do not contain information on the period between 1985 and 1989, it should be posited that - in keeping with the trend in the preceding years - the rate of detectability and convictions in this period was on the decline. Furthermore, in order to perform a quantitative analysis of the phenomenon of espionage, analyses included in graduation papers by officials of law-enforcement agencies were used.

The information characterising the level of the counter-intelligence threat and the scope of US intelligence activity against Poland in 1970-1989 was obtained owing to a survey of the material and documents held at the archives of the Institute of National Remembrance. The analysis drew on: (1) the training material provided by the Ministry of the Interior and the Ministry of Defence, (2) analytical documents of the Polish civil and military intelligence and counter-intelligence services, (3) materials and documents contained in the so-called premises dossiers, chiefly concerned with diplomatic posts in Poland, (4) graduation papers by officers of Civic Militia [Pol. Milicja Obywatelska], as well as officers of the Polish intelligence services, defended at ministerial universities.

One of the most challenging problems concerning the study of the materials generated by government authorities in the period in question is their reliability. The same goes for the analysis of the convictions for espionage. Certainly, the content of the analytical documents and other types of materials produced by the Ministry of the Interior and the Ministry of Defence was influenced by the ideology of the then political system, and by extension by the political situation of the Polish People's Republic in international relations. The effect of such factors can be illustrated with the materials concerned with Germany's possible revisionism as to Poland's western border (Cf. Rosicki, 2016, pp. 167-189). As for court verdicts on espionage, attention should be drawn to the possibility of convictions for espionage, which under the existing legislation and the judicature would not be the case. This mainly results from the fact of reducing the repressiveness of the law as far as the elimination of crime against the state is concerned, but also from the changes to the statutory features of this kind of crimes.

Undoubtedly, the issue of the reliability of the documents generated by the socialist state's repressive apparatus remains open (Brzechczyn, 2012, pp. 53-77). Therefore, in the analysis of the documents dating from the period in question an appropriate dose of reason is advisable, while in the methodological approach it should be stressed that the two paradigms - i.e. narrativism and positivism - are not fault-free as regards analysis of historical materials (Brzechczyn, 2013, pp. 513-518; Brzechczyn, 2006, pp. 37-53).

In order to demonstrate the necessity to take with a grain of salt the content of the materials generated by the Ministry of the Interior and the Ministry of Defence, in the period under analysis, one can make liberal use of the theory of speech acts by J. L. Austin (Austin, 1962; Austin, 1993; Levinson, 2010). And so it should be emphasised that the content is not only intended to convey information to recipients, but it also creates some kind of social facts, e.g. by generating "a state of threat of espionage" or "a sense of being threatened with espionage." Hence, while analysing the content concerned with the threat of espionage, it is worth following J. L. Austin in considering at least three aspects: (1) locutionary, (2) illocutionary, and (3) perlocutionary. 
In the first case (locutionary aspect), one should allow for the specificity of the language used by the creators of the information under analysis. Here, one can distinguish a special kind of linguistic nomenclature concerned with the dominance of the ideology specific to the then political system in Poland. In the second case (illocutionary aspect), account should be taken of the persuasiveness of information, as well as the sender's intention, i.e. that which he intends to achieve by way of the generated message. The effectiveness of the impact of the created material may serve as the assessment of the value of this aspect. Exerting influence with the aid of a warning may be oriented towards the service's own needs, e.g. in order to stimulate activity in the field of counter-intelligence work undertaken by the service operatives, but also towards the needs concerned with influencing a variety of political entities, e.g. with a view to demonstrating the reason for the service's existence and its significance for the state's security. As regards the third aspect (perlocutionary aspect), the persuasiveness of the information should be taken into consideration within the scope of attainment of secondary goals. These can include willingness to throw recipients - e.g. various political entities - into a certain state. Thus, it is a mechanism geared towards attaining certain mental states; politicians' satisfaction with having effective institutions for espionage elimination may be one of such states (Cf. Austin, 1962; Austin, 1993).

\section{A general description of the phenomenon of espionage in Poland}

\subsection{A quantitative description of espionage}

According to the data of the Ministry of the Interior, in the period of 1944-1984 the number of convicted spies in Poland exceeded 2160; however, it must be noted that the statistics cover convictions only, but do not fully characterise the phenomenon of espionage or the activity of foreign intelligence agencies in Poland in the period in question. The number of individuals convicted of espionage also included persons related to the so-called "reactionary western centres," which more often than not were associated with institutions connected with the Polish government-in-exile. The greatest section of the spies convicted in 1944-1984 worked for the US (33.2\%), England (19.9\%), France (10.1\%), West Germany $(9.5 \%)$, Sweden $(0.7 \%)$, and the so-called "reactionary western centres" $(21.3 \%)$. The remaining cases, that is more than 5\%, were concerned with espionage for the benefit of other countries (Cf. Rosicki, 2016, pp. 167-189). Some authors point out that the number of spies convicted of espionage against Poland is unrealistic inasmuch as the number of convicts does not correspond to the acts of espionage that would constitute prohibited acts under different political conditions (Piecuch, 1996, pp. 406-407). Besides, of particular note are the remarkable disproportions between espionage conviction figures in different periods. For instance, $82 \%$ of the convictions took place in the period of $1944-1956,9.5 \%$ convictions took place in the period between 1957 and 1969, and the remaining ones (i.e. 8.5\%) were effected from 1970 until $1984 .^{1}$

${ }^{1}$ Percentage calculations and data set concerned with the number of convictions for espionage - author's own work. The calculations and comparison have been performed on the basis of the Ministry of the Interior (Office "C") data from 1986. 
Given the above data it follows that the US dominated the spying activities as expressed in the number of convictions. The US prevalence in the number of convictions is also to be observed in the following periods: 1944-1956 (24.6\%), 1957-1969 (54.3\%), 1970-1984 (40\%). As for the first of the above periods, the lower percentage share of the US results from the large-scale spying activity for the benefit of the UK and "reactionary western centres." In the period of 1970-1984 74 individuals were convicted of espionage for the US. In that period, the 1970s witnessed the greatest number of convictions for espionage for the benefit of the US, whereas the 1980s saw their decline, which also reflected the trend in the overall number of convictions for this type of activity in Poland [See Fig. 1]. ${ }^{2}$

Figure 1. Number of convictions for espionage in Poland in 1970-1984

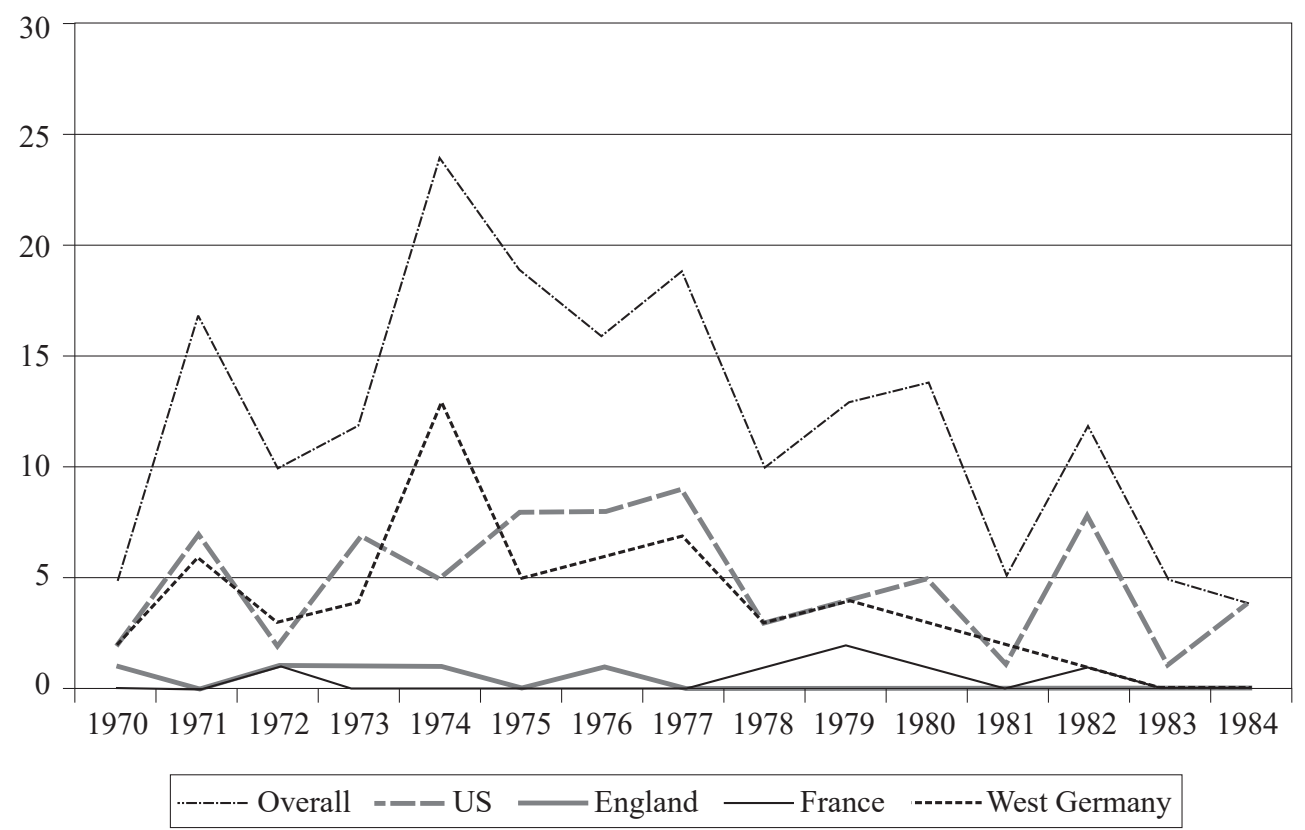

Source: Author's own work on the basis of the Ministry of the Interior data from 1986.

In order to present the quantitative aspects of espionage against Poland, one can also use the analyses included in graduation theses written by officers of law-enforcement agencies at ministerial schools (Sabik, 1988; Ciecholewski, 1984). According to the analyses of the materials of the Investigation Office at the Ministry of the Interior, it is possible to point out that in the decade of 1976-1986 fifty cases were being investigated for espionage, that is in relation to the violation of Art. 124 of the Criminal Code. As a result of the ongoing proceedings, forty three persons were convicted for this crime, two cases were suspended, three cases were dismissed, and two cases were in progress. It follows from the analysis that the years 1980 and 1982 saw the greatest number of cases in the period in question, that is the above years accounted for $36 \%$ of the conducted

\footnotetext{
${ }^{2}$ See above.
} 
cases and $37 \%$ of convictions [See Fig. 2]. ${ }^{3}$ Undoubtedly, the number of proceedings and convictions in these years was affected by Poland's unstable social and political internal situation. In that period two capital punishment sentences were passed, but they were not executed on the grounds that a judgment was passed in default, and a pardon was granted (Cf. A Catalogue..., 1986).

Figure 2. Number of conducted proceedings and number of convictions for the crime of espionage (1976-1986)

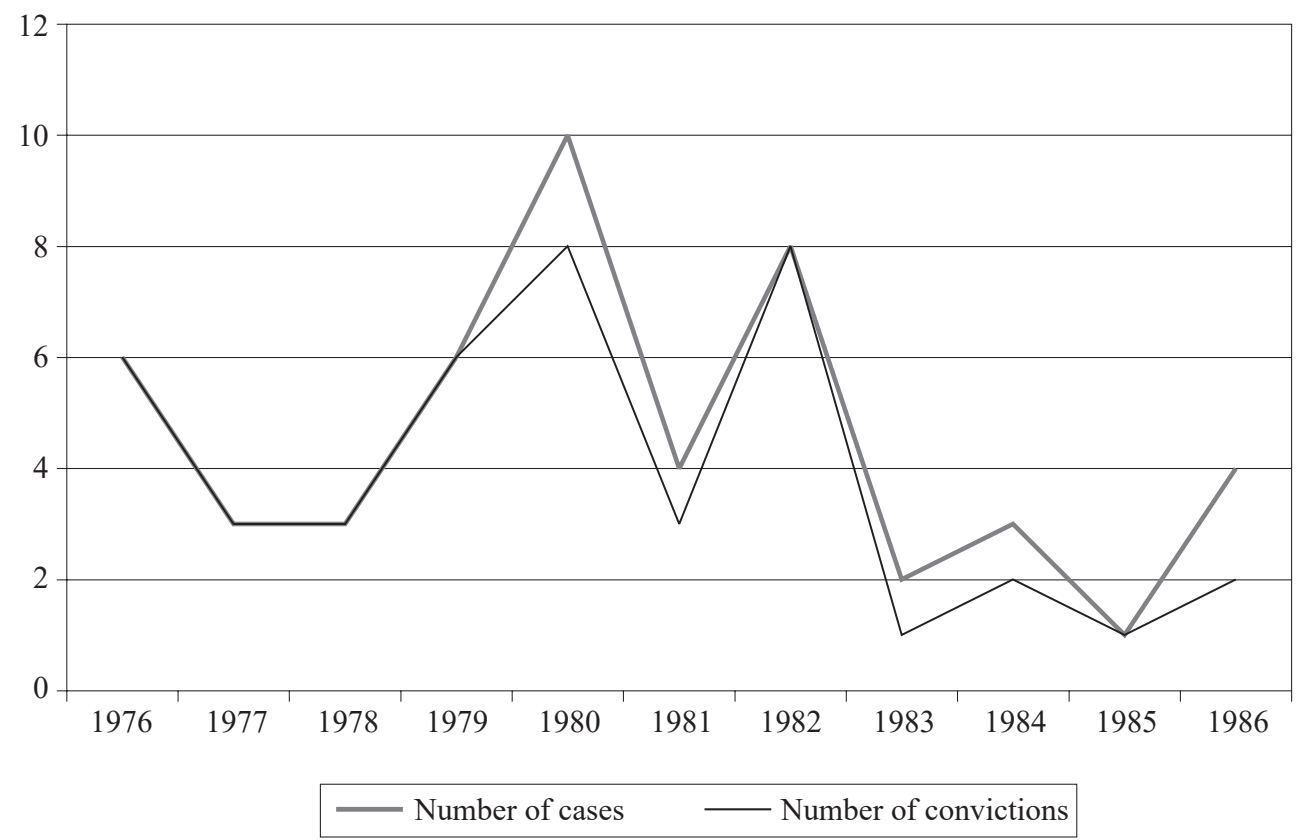

Source: Author's own work on the basis of data: Sabik, 1988; Investigation Office of the Ministry of the Interior (juxtaposed with the data: Ciecholewski, 1984; Majkrzak, 1990).

According to the analysis performed by R. Sabik in 1976-1986, the biggest group of convicts was made up of Polish citizens $(88 \%)$, where the predominant sex was male (96\%), and the individuals most frequently committing the crime were aged $31-40(40 \%)$. Of great significance for the perpetration of the crime was the education of the perpetrators and their positions, because in $50 \%$ of the cases the individuals had a secondary education (including an incomplete secondary education), and in $34 \%$ of the cases the individuals had a university education; as for the positions held, $19 \%$ of the individuals were in executive positions. Besides, it is worth noting their motivation, where $60 \%$ of the cases were motivated by material gain, whereas $24 \%$ of the cases were motivated by a hostile attitude to the political system (Sabik, 1988). ${ }^{4}$

${ }^{3}$ Percentage calculations and data set - author's own work. The calculations and the data set have been made on the basis of the data contained in: Sabik 1988. The data have been juxtaposed with the data in: Ciecholewski, 1984; Majkrzak, 1990.

${ }^{4}$ See above. 


\subsection{A legal description of the espionage activity}

Political and legal factors were of considerable importance for the incidence of convictions for espionage in the individual periods. The political factors include the processes of political transition in Poland - transformation from the stage of state consolidation in the wake of the Second World War to the subsequent stages, that is the stage of Stalinism and the stages of liberalisation of the system of people's democracy (a socialist state). The political factors had a considerable effect on the legal domain, which came to be expressed in the introduction of new legal regulations in the field of criminal law. The year 1946 saw the issuance of the Decree on particularly dangerous crimes in the period of the reconstruction of the State, and the year 1949 - the Decree on the protection of state and official secrets, while the year 1955 - the Act on the transfer of jurisdiction over criminal cases of natural persons, officials of public security authorities, Civic Militia and Prison Service from military courts to common courts (Journal of Laws 1946 no. 30 item 192; Journal of Laws 1949 no. 55 item 437; Journal of Laws 1955 no. 15 item 83). Of great significance for the liberalisation of the scope of penalisation of espionage was the coming into force of the new Act of Criminal Code in 1970 (Journal of Laws 1969 no. 13 item 94). The quality of the applicable regulations changed, because the previous criminal law regulations were of low legislative quality, and by extension were characterised by less distinct objective features of crime against the state, including crimes concerned with espionage (Cf. Andrejew, Sawicki, 1949; Andrejew, Pławski, 1953; Siewierski, 1958; Bafia, Hochberg, Siewierski, 1965).

It is worth emphasising the specificity of legal solutions concerned with the penalisation of espionage in the period in question. The main features of these regulations include a differentiation between "the crime of espionage" and "the crime of high treason."

In the latter case the crime could be committed by a Polish citizen or a person without Polish citizenship (a common crime). As for this crime, any form of "taking part in the activities of a foreign intelligence service," including activities consisting in "acting for the benefit of a foreign intelligence service" by "providing it with information" were penalised. Also, any activities involving "organising" intelligence activities or "leading" them, which constituted an aggravated crime of espionage, were subject to a penalty (Art. $124 \S 1 \mathrm{CC}$ ). This type of crime, with enumerated attributes, lacked an equivalent in previous regulations (Cf. Ciecholewski, 1984, pp. 56-57). The regulations also penalised - according to a part of the doctrine - a special form of preparation which consisted in "collecting or storing information in order to provide it for a foreign intelligence service" and activities consisting in "undertaking" activity for the benefit of a foreign intelligence service (Art. $124 \S 2$ CC) (Cf. Świda, 1978, p. 457; Hoc, 1985, pp. 97-108). The application of Art. $124 \S 2$ was possible only when it was impossible to apply Art. $124 \S 1$ of the Criminal Code. This resulted from the fact that the attributes specified in $\S 1$ covered in their scope the attributes specified in $\S 2$ (Supreme Court Verdict of 29.07.1977, Rs 8/77). In the enumerated attributes of the crime, the Polish legislator did not qualify the kind of information he had in mind, that is from the perspective of criminal accountability it did not matter whether the conveyed information was marked by a special clause or of a damaging character (Cf. Bafia, Mioduski, Siewierski, 1971, p. 317, Supreme Court Verdict of 17.08.1979, Rs 4/79). In the case of "undertaking" the activity 
for the benefit of a foreign intelligence service, a mere declaration was not enough, that is declaring a readiness to work - for this crime to be realised it was necessary for the offer to be accepted (Supreme Court Resolution of 12.12.1973, U 2/73). In the event of no will to accept the offer or a lack thereof, it was possible to convict an individual for an attempted crime of this kind (Adrejew, 1978, p. 99), however the doctrine was equivocal in this respect (Chybiński, Gutekunst, Świda, 1971, p. 32; Hoc, 1985, pp. 100-108). The fact that the term "a foreign intelligence service" was underdefined in the act also posed a problem, as this resulted in a lack of specification as to the addressee of the declared readiness to collaborate (e.g. hence it was unclear whether the legislator had in mind an operative of a specific intelligence service, or any representative of a foreign post or organisation) (Hoc, 1985, p. 68). Still, the criminal law doctrine adopted a narrow understanding of the concept of "a foreign intelligence service," that is a specialised service of a foreign state or an organisation whose object of activity was to clandestinely collect and process information for the purposes of one's own state or organisation (Bafia, Mioduski, Siewierski, 1971, p. 228; Kubala, 1975, p. 84). Arguably, the narrowest definition of intelligence in the doctrine in the period in question was presented by S. Pikulski, who reduced the notion of intelligence to specialised state authorities whose aim was to conduct spying activity (Pikulski, 1980, pp. 82-83).

Interpretation of Art. $124 \S 2$ also posed interesting problems; for instance, S. Hoc demonstrated that in this regulation the legislator penalised sui generis preparation. Therefrom followed the assumption that all the attributes mentioned in this regulation should be analysed in connection with other attributes of the statutory and spontaneous stages of preparation (Art. $14 \S 1-2 \mathrm{CC}$ ). According to S. Hoc the assumption is to apply to both "collecting" and "storing" information, as well as "undertaking" activity for the benefit of a foreign intelligence service (Hoc, 1985, pp. 97-108). This line of reasoning appears to be highly erroneous, because given the legislation in force back then the legislator penalised preparations for these prohibited acts in a separate article (Art. $128 \S 1$ $\mathrm{CC}$ ); what is more, he pointed to a special type of active repentance concerned with the attempted deeds (Art. $128 \S 3 \mathrm{CC}$ ). It seems irrational and strange for the legislator to have created a concept of preparation for preparations and attempted preparations, and so the interpretation offered by S. Hoc appears to be at least misguided. Yet, this kind of interpretation became established in judicial glosses, and also influenced interpretation of similar solutions in the new legislation in force in the 1990s. But in the new legislation in force the legislator did not penalise preparations for the acts identical with the acts mentioned in Art. $124 \S 2 \mathrm{CC}$, so the interpretation of the new legal solutions as sui generis preparation makes sense.

In the latter case, that is high treason, subject to a penalty was a situation in which a Polish citizen participated in "activity of a foreign state" (or "a foreign organisation"), where the participation was oriented towards specific and hostile goals (depriving the state of independence, detaching a portion of the territory, overthrowing the system, weakening the state's defences (Art. $122 \mathrm{CC}$ ). Besides, subject to a penalty was the situation where a Polish citizen while "acting for the benefit of a foreign intelligence service aims to damage the foundations of security and defence" of the Republic of Poland. Thus, it is a form of espionage whereby a Polish citizen participates in a foreign intelligence service, thereby harming the security and defence of the state (Muszyński, 1972, 
pp. 55-72; Adrejew, 1978, p. 97). An example illustrating such activity is conveying to a foreign intelligence service information on military mobilisation and army unit deployments (Cf. Muszyński, 1971, p. 90). I. Andrejew, one of the co-authors of the Criminal Code of 1970, pointed out that convictions on the basis of this article were very rare (Adrejew, 1978, p. 99).

\section{Areas of interest of the us intelligence in Poland}

\subsection{Activity of diplomatic posts}

According to the analyses by the Ministry of the Interior and the Ministry of Defence, based on the work of the civil and military counter-intelligence services, the US Embassy in Warsaw housed a resident spy's station of the American intelligence. The residency was to reflect the significance of particular special services of the US, and so it was pointed out that the embassy held representatives of the CIA (Central Intelligence Agency), DIA (Defence Intelligence Agency), NSA (National Security Agency) and INR (State Department Bureau of Intelligence and Research), as well as other institutions (Affet, 1978; Pleskot, 2013a, pp. 332-340). However, the greatest significance was attributed to the CIA, which was connected with the institutional standing of the CIA in the US - the Agency was the service which coordinated the activities of all intelligence agencies (Pleskot, 2013a, pp. 335). From the documentation of the Ministry of the Interior it follows that the operation of the American residency was oriented towards six areas of interest: (1) defence, (2) political issues (the workings of the state apparatus of the Polish People's Republic), (3) the operation of the political opposition, (4) economy, (5) Poland's relations with its allies, (6) the operation of the Church in Poland (Information on..., 1988; Rosicki, 2016, pp. 167-189).

On the basis of the data dating from 1988 it is possible to point out that the American intelligence residency at the US Embassy in Warsaw comprised 32 staff members, which made up 55\% of the professional personnel of the embassy. The staff members and formal co-workers of the civil intelligence services included 17 persons. Their representatives were present in, inter alia, the culture and press, economic, political and consular departments. Officers of the military intelligence services manned the military attaché office, the telecommunications department, and had their own representatives in the political, economic and science $\&$ technology departments. The group of resident spies was supported by individuals who came to the embassy for a shorter stay (Information on..., 1988).

The Polish counter-intelligence paid particular attention not only to the operation of the embassies, but also of American consulates. According to the analyses performed by the Polish services, the main operational goal of the US Consulate in Poznań towards the end of the 1970s was to gather information useful for pursuing a US foreign policy targeted at the Eastern Bloc states. Still, as the services themselves emphasise, as a result of the consulate's limited staff potential coupled with its wide material scope of interest the specificity of the obtained information was rather limited. The main subjects brought 
up by the consulate employees during meetings and other forms of coming into contact with Polish citizens were concerned with the political operation of the party and state authorities, Poland's current economic situation and the relations between the state and the Catholic Church. In the documented talks the representatives of the US consulate remarked on the fragile foundations of Poland's economic development. In their opinion, Poland owed its development to loans obtained from western countries. According to consulate head F. A. Riggs, the loans taken out by Poland were paid off with foreign currencies, $60 \%$ of which was earmarked for debt repayment, and $40 \%$ for new purchases. The consulate also performed analyses of product prices currently applicable on the market (Document ref. no. CF-002287/80/ks, pp. 1-10).

It should be noted that the US Consulate in Poznań was kept under permanent surveillance and intelligence-gathering control, as were the travel destinations of the consulate's employees (Cf. Instruction no. 0023 on the operational protection of the members of the US post resident spies along with the current list of resident operatives, 1983). Hence, it is to be assumed that the Polish services had an insight into the journeys made around Poland by the consulate employees meeting Polish citizens. According to the analyses, a considerable level of activity was shown by the press \& culture department. This activity was described as "the most offensive and regular;" it was also deemed effective, as it was directed at the Polish academic, journalistic, cultural and artistic circles. According to the Polish services' analyses, this type of activity constituted both a way of influencing particular milieus and a way of obtaining the greatest possible amount of information about the state and society. It was indicated that - given the political conditions - the employees of the US diplomatic posts maintained extensive relations with the Polish academic circle (a number of Polish universities) (Document ref. no. CF-002287/80/ ks, pp. 1-10). The analyses presented by the Polish counter-intelligence service also point out that in their activity the US Embassy personnel emphasised their moral and material support of the Polish opposition. The relations with the opposition were used to obtain information about: (1) the opposition plans of action, (2) description of detention centres for oppositionists during the martial law, (3) description of the public sentiment, (4) description of the political situation in Poland. According to the source materials the representatives of the American diplomatic posts were particularly interested in the opposition activity of the "Solidarność" leaders (Information on..., 1984).

In the analyses dating from the mid-1980s the Polish services indicated that the crucial sources of information for the employees of the US Consulate in Poznan included Americans teaching English at Polish universities, individuals sympathising with the opposition and representatives of the clergy (e.g. Church hierarchs, members of the Dominican Order, Catholic press journalists) (Information on the activity of the US Consulate in Poznan in 1985, 1986). According to the Polish services, one of the ways of establishing contact with Polish citizens was through the consulate library, where books and periodicals were made available. It is estimated that in 1979 every day the consulate was visited by $20-30$ persons with a view to taking advantage of the library holdings. Besides, the US Consulate in Poznań conducted cultural activity, e.g. by organising film screenings. For instance, in 1979 the consulate was visited by 22,000 persons $-60 \%$ to obtain visas, $25 \%$ to use the library and $15 \%$ to take part in the film shows or for other reasons (Document ref. no. CF-002287/80/ks, pp. 1-10). In the mid-1980s the signifi- 
cance of the cultural activity at the embassy was to grow, which was due to the activity of consul D. Spikes, ${ }^{5}$ as well as easier access to film technologies (VHS cassettes and players). For instance, compared with the year 1984, in 1985 the number of visitors taking advantage of the library, film shows and the distributed periodicals rose from 5,800 to more than 10,000 persons (Information on the activity of the US Consulate in Poznan in 1985, 1986). In general, in 1985 the consulate was visited by 31,000 persons, $34.2 \%$ of whom visited the consulate library, whereas $65.8 \%$ of the visitors were there to take care of some office business. A conspicuous group was made up of teenagers (21.6\%). It was established by the Polish services that a considerable group of visitors to the consulate was one composed of individuals holding university degrees and employees of Poznan universities (An analysis concerned with the individuals contacting the US Consulate in Poznań in 1985, 1986).

As regards the evaluation of the operation of the American consulate in Poznan, it was also pointed out that it might have had some significance for the workings of resident intelligence operatives. The significance of the consulate for the activity of the resident operatives was related to the location of the city of Poznan. According to the analyses of the Polish services, the consulate was used for the so-called "penetrative activities" by the employees of the army attaché office at the US Embassy in Warsaw, which was to be demonstrated by the visits paid by American diplomats from the military department. Besides, it must be noted that Poznań is located on the way from Berlin to Warsaw, hence the conspicuously considerable number of passages through Poznan made by employees from other departments of the US Embassy (Information on the activity of the US Consulate in Poznan in 1985, 1986). According to the 1983 register of the members of the US intelligence residency in Poland, at the Poznań consulate two persons were identified - among the ranks of the resident spies at the US consulate in Poznań reckoned were Janet Demiray $^{6}$ (a culture \& press consul) and Souad Demiray ${ }^{7}$ (A list of the members of the US post resident station, 1983).

${ }^{5}$ Daniel Spikes - a culture \& press consul at the US Consulate in Poznan in the 1980s. In Poznań D. Spikes stayed as from June 1985; earlier he had worked as a press consul at the US Embassy in Rome. By education he was a historian, and was proficient in Polish. Information obtained from: Document ref. no. CF-0289/87/KS.

${ }^{6}$ Janet Demiray (Collins) - in diplomatic service as of 1970. She performed diplomatic functions in Ankara (1971-1972), Nairobi (1975-1978) and Moscow (1979-1981). She also held a post of special affairs counsellor at United States Information Agency (USIA). On the basis of the intelligence gathered by the Polish services, she knew Polish and Russian. In Poland she fulfilled diplomatic functions as of 1982. At first at the US Embassy in Warsaw she covered for the first secretary of the culture and press department, then she took up a post in Poznań. According to the Polish services, J. Demiray was also involved in selecting candidates for trips to the US on account of the USIA scholarship programs (Information cited in: A description of the foreign diplomatic personnel of the US Consulate in Poznan', 1984). In the 1990s she performed diplomatic functions also in Belarus (Cf. Belarus - Expulsion of diplomats, 1997).

${ }^{7}$ Souad A. Demiray - of Turkish descent, husband of Janet Demiray. After getting married to Janet Collins, he became a US citizen. According to the Polish services, despite not being a consulate employee, he had a diplomatic passport and was allowed to access confidential and secret matters of the post. Before arriving in Poland, he stayed with Janet Demiray in the USSR. On the basis of the intelligence gathered by the Polish services, he spoke English, German and Russian. The Polish services compiled S. A. Demiray's detailed personal profile and a description of his financial status (Information cited in: A description of the foreign diplomatic personnel of the US Consulate in Poznan, 1984). 
3.2. Threat of epsionage gathering knowledge about the condition of economy, industry and the academic circle

According to the documentation of the Ministry of the Interior, the economic issues were seen as a high priority in the US espionage against Poland. In the 1980s, the US intelligence service was interested in the effect of the sanctions on the condition of the Polish economy. The main issues arousing the interest of the US included: (1) pursuit of the economic policy and the economic potential, (2) pursuit of the energy policy and the energy potential, (3) economic cooperation within the Council for Mutual Economic Assistance, (4) debt, (5) pursuit of the export policy. According to the Polish services, in the second half of the 1980s, the economic department of the US Embassy in Warsaw began orienting its activity towards more detailed information on the economic issues. The American services paid particular attention to obtaining information about the factors hindering the resolution of economic problems in Poland. Such conclusions were drawn on the basis of the intensified relations between representatives of the US diplomatic posts and representatives of the Polish economic institutions of various echelons, as well as relations with the representatives of academic institutions (e.g. universities, research institutions) and the mass media (Information on the penetrative-explorative activity of the US diplomats oriented towards gathering knowledge about the economic situation in Poland, 1986).

According to the Polish services, one of the channels through which information was obtained was the scholarship system targeted at the individuals who came within the US compass of interest. Besides, it was widely accepted that the US used the visa system to gain knowledge about the economy. The practice of interviewing individuals applying for visas in the visa application procedure played a particularly special role. It afforded a perfect opportunity to ask questions about the general economic situation in the country, but also about the economic situation in the workplace (Ibidem).

The Polish services saw a more structured visit of the US diplomatic representatives to strategic or ordinary industrial establishments as a way of obtaining economic information. This can be illustrated with the example of the visits paid by D. Swartz and R. Albright to light and heavy industry facilities in the years 1985-1986, including a visit to Nowa Huta (Ibidem).

It should be pointed out that the Polish services placed great emphasis on obtaining information concerned with science and technology in their intelligence activity conducted in the US, which can be exemplified by the workings of M. Zacharski (Information on the preventive activity of the US intelligence services towards American scholars, 1984; Zacharski, 2009; Gułhak, Pleskot, 2014, pp. 405-450). Similarly, it was assumed that the American services placed equally great emphasis on gathering intelligence concerned with science, patents and state-of-the-art technologies in Poland. According to the analyses of the Ministry of the Interior, in the socialist countries the US recruited science and technology personnel who were to be employed at a "military-industrial complex." The US intelligence activity was to be particularly focused on the centres: (1) conducting research on an international level, (2) dealing with issues directly and indirectly related to security, (3) dealing with research into military technologies (Information on the activity of the US intelligence services in the spheres of science, technology and invention 
in Poland, 1988). In general, it can be concluded that in the 1980s the significance of technological intelligence increased. This can be illustrated with the Polish services' estimation whereby in 1987 as much as $40 \%$ of the intelligence operations by the American and British resident spies in Poland was concerned with technological intelligence (Sroka, 1988, p. 17).

The apprehension of the US citizen A. Mueller in 1987 may serve here as an example of infiltrating the academic circle and engaging in scientific and technical intelligence. According to the Polish counter-intelligence service, A. Mueller was employed at the US intelligence resident office, and acted undercover as a secretary of the embassy's political department. It is indicated that A. Mueller had been groomed for this kind of activity within the Polish territory, as he had been dispatched to Poland by the CIA as early as 1975 through the academic scholarship channel. The Polish counter-intelligence records show that in that period A. Mueller focused on the so-called "biographical intelligence," that is on performing personal analyses of the Polish academics. According to the materials gathered by the Polish services, the guidelines dispatched by A. Mueller to one of the agents in Poland included obtaining information on military technologies concerned with ballistics, radio-electronics, radiolocation and aviation. Given his diplomatic status, A. Mueller left Poland before he was officially declared a persona non grata (Kaufman, 1987; U.S. Diplomat Quits Poland After Accusation of Spying: Caught While Meeting Contact, Warsaw Says, 1987; Poland Accuses U.S. Diplomat of Spying, 1987; Information on the activity of the US intelligence services in the spheres of science, technology and invention in Poland, 1988).

Another example of scientific and technical intelligence is the activity of P. Smith and R. Virden, who - according to the Polish counter-intelligence service - were members of the US intelligence residency on the Polish territory, and acted undercover. P. Smith and R. Virden allegedly led, as an agent, one of the former Polish journalists and an employee of the Polish services - M. Dastych. ${ }^{8}$ The Americans used the scholarship system and recruited him during his scholarship stay in the US in the 1970s (M. Dastych presented different information about the recruitment). The spying activity of M. Dastych was to include such fields as computerisation schemes for Poland and trade in new technologies. Besides, M. Dastych participated in the selection process of Polish citizens for US schol-

${ }^{8}$ Mariusz Dawid Dastych (1941-2010) - studied in Poland, inter alia, political science, was a collaborator of many press agencies (e.g. a Polish, Japanese, Soviet and Hungarian one). At the beginning of the 1960s he entered into collaboration with the Polish intelligence service. In 1973 he was recruited by the CIA during his stay in Southern Vietnam (other literature sources cite a different place and time of recruitment). M. Dastych claimed that his first informal contact with the CIA was in Northern Vietnam, when he was working for the International Commission of Control and Supervision (ICCS). By his account, official cooperation with the CIA began on his initiative in 1973. In Paris he was subjected to a polygraph exam in August of that same year, which was a CIA vetting method. In 1976-1981 he worked as an officer of the Polish intelligence services. In 1982-198 he worked in Warsaw for the Japan External Trade Organization (JETRO), whose main goal was to promote the export of Japanese products. In 1987 he was apprehended and sentenced to 8 years' imprisonment on a count of espionage for the benefit of the US and Japan. Because of the political transformation in Poland, M. Dastych did not serve the full term. Having been released from prison, he worked as a journalist and writer. In 1996 under suspicious circumstances died his son, a student of the University of Bradford. Some literature sources point to a possible poisoning during his stay in the UK, which might have been related to his father's activity (Cf. Stawiarski, 2007; Mir, 2008; McLeod, 2010). 
arship programs (allowing for the participants' susceptibility to US recruitment). By the account of M. Dastych himself, his information was to be useful for the CIA and NATO in breaking up the ring of Soviet spies gathering knowledge about nuclear technologies in Western European countries (e.g. France, Germany and Italy) in the second half of the 1970s. Allegedly, he also rendered his analytical services concerned with monitoring threats of nuclear technology proliferation to foreign intelligence services in the first half of the 1990s (Information on the activity of the US intelligence services in the spheres of science, technology and invention in Poland, 1988; Stawiarski, 2007; Mir, 2008).

Another example of scientific and technical intelligence is the activity of S. Mull, who back then was one of the employees of the political department of the US embassy in Warsaw. ${ }^{9}$ According to the Polish services he was using the relations with academics to obtain information from employees of Wrocław universities. Like A. Mueller, S. Mull had to leave Poland in 1986 (Polish Films of an American Shown as Evidence of Spying, 1986; Yuenger, 1986; Diehl, 1987). The American press presented S. Mull's problem as attempted revenge on the diplomat for maintaining relations with Polish oppositionists and Church representatives, while the Polish services presented S. Mull's operations as typical US spying activity.

The Polish services also focused their attention on specialists employed at US diplomatic posts. Analyses of the presence of the science and technology counsellor Prof. J. J. Loferski ${ }^{10}$ at the US Embassy in Warsaw may serve here as an example. Before taking up the post, the scientist was already in Poland, but as a scholarship holder he served his internship at a facility of strategic significance for security, that is the Institute of Nuclear Research in Świerk (a centre located near Warsaw). According to the Polish services, J. J. Loferski used earlier contacts and acquaintances while he performed his function at the US Embassy. The Institute of Nuclear Research in Świerk was of no mean significance for the Polish counter-intelligence, because in the 1980s more than 30 independent researchers from this facility did not return to the country from scholarship programs or other trips abroad (Information on the activity of the US intelligence services in the spheres of science, technology and invention in Poland, 1988).

9 Stephen Mull - a graduate of Georgetown University (a bachelor's degree in international politics - 1980), began his diplomatic career in 1982. He worked at a number of diplomatic posts, e.g. in Indonesia, Lithuania and the Republic of South Africa, as well as in Poland in the 1980s. S. Mull speaks Polish. In 2012-2015 he served as the US ambassador to Poland. In 2015 he was appointed as the Lead Coordinator for Iran Nuclear Implementation, tasked with carrying out the terms of the Joint Comprehensive Plan of Action (JCPOA), which was signed 14 July 2015 (Diehl, 1987; Komorowski decorates outgoing US ambassador Mull, 2015).

${ }_{10}$ Joseph John Loferski (1925-1997) - born in Hudson (USA), in the years 1943-1946 he served in the US army, in 1948 took a bachelor's degree at Scranton University, a master's degree in 1949, and a Ph.D. in 1953 at the University of Pennsylvania; he spoke fluent Polish, and was also communicative in French, German and Russian. After taking the academic degrees, he was involved with RCA Laboratories at Princeton (1953-1960). He was a physicist and a professor of engineering at Brown University; in 1967-1968 he worked at the European Space Research and Technology Centre (ESTEC) in the Netherlands; he was also a NASA consultant. In 1986-1987 he was a science \& technology counsellor at the US Embassy in Warsaw, and in 1988-1991 was a member of the American-Polish Committee of Science and Technology Cooperation. His knowledge of Polish and Russian allowed him to translate Central European technical texts into English. J. J. Loferski was regarded as a pioneer of photovoltaic cells (Wierzbianski, 1996; Hilchey, 1997). 
The Polish services considered every scholarship activity and the American institutions that supported it to be threat of science and technology espionage (Cf. Lubaszewski, 1989, pp. 53-56). The evaluation of the activity of the United States Information Agency (USIA) in general and in Poland may serve here as an example. In the 1980s the US made efforts to restore the scholarship programs to the condition known before the restrictions imposed by Poland. According to the Polish services, the increased US scholarship activity was to contribute to the intelligence and information gathering in the fields of: (1) nuclear programs, (2) IT \& robotics solutions, (3) medicine and biology advancement, (4) technological processes, (5) state of knowledge and progress in the fields of mathematics and physics (Information on the activity of the US intelligence services in the spheres of science, technology and invention in Poland, 1988).

Besides, the American companies operating on the Polish territory played no small part in technology intelligence. According to the Polish services in the mid-1980s, in operation were 41 American companies, 16 of which had their agencies in Poland, and the bosses of 8 of them maintained relations with the US intelligence personnel (Ibidem). The US intelligence service was interested in the Polish state-owned enterprise called a Foreign Trade Centre (Pol. Centrala Handlu Zagranicznego - CHZ), which was authorised to deal in foreign currencies and engage in trade with foreign entities. It was a natural environment for educated people who spoke foreign languages, were well-connected and travelled to western countries. One of the many examples of espionage related to the activity of the $\mathrm{CHZ}$ was the case of Leszek Ch. (an employee of the Ministry of the Heavy and Agricultural Machinery Industry), who in 1979 was convicted on a charge of espionage for the benefit of the US. Leszek Ch. had been recruited as a CHZ representative at the Bangkok office; it was also there that he had been recruited by a foreign intelligence service. As of the 1960s Leszek Ch. had been conveying to the US intelligence officers information on, inter alia, the $\mathrm{CHZ}$ employees and facilities. On return to Poland, he continued his spying operations for the benefit of a foreign intelligence service, handing over information on his activity and the activity of the Polish companies operating on the Western markets (Ciecholewski, 1984, pp. 124-126; A Catalogue..., 1986; Lubaszewski, 1989, pp. 33-41).

\section{Conclusion}

The main aim of the text is to describe the scope of the recognition of the US threat of espionage by the Polish intelligence services. The analysis presents the Polish intelligence services' state of knowledge and habits of mind concerned with the risks resulting from the US espionage against Poland in the 1970s and 1980s. In order to elaborate the objective scope of the research problem addressed in the paper, the following research questions have been presented: (1) What was the scope of the recognition of the US espionage by the Polish intelligence services in the period of 1970-1989?, (2) What areas of interest in the US espionage against Poland were predominant in the period of 1970-1989? The individual questions have been linked with the following conclusions (account has also been taken of the conclusions concerned with the critical analysis of the source material and documentation): 


\section{(1) First question conclusions}

It should be pointed out that between the 1940s and the end of the 1990s the trend in convictions for crimes of espionage was on the decline. This state of affairs was related to the influence of political and legal factors. The political factors included the process of political transition in Poland, which consisted in transformation from the stage of state consolidation in the wake of the Second World War to the stage of Stalinism and the stages of liberalisation of the socialist state. Alongside the influence of the political factors, the law was amended, as was the scope of accountability for crimes against the state, which included acts of espionage. According to preliminary data, in the period of 1970-1984 seventy four persons were convicted for espionage for the benefit of the US and against Poland. The 1970s accounted for the greatest number of convictions for espionage for the benefit of the US, while the 1980s saw some decline. In the years $1970-1984$, of the total number of convictions $40 \%$ of convicts acted for the benefit of the US.

In the period under analysis the Polish intelligence services were quite skilful at recognising risks posed by the activity of resident spies planted at US diplomatic posts. This followed from the fact of on-going counter-intelligence operations targeted at diplomatic facilities, diplomats and diplomatic personnel. Still, as regards combating the activity of resident spies quite a difficulty was posed by the very status of a diplomat in a foreign state. With the benefit of the development of new communication technologies, intelligence services face bigger problems recognising real intelligence threats to Polish citizens. The Polish intelligence services have limited means of recognising the threat posed by recruitment of the Polish citizens staying abroad or leaving the country periodically. In the year 1987 the Polish services identified more than 200 recruitment attempts directed at Polish citizens temporarily staying abroad. In the second half of the 1980s the significance of the Federal Republic of Germany and West Berlin again increased as far as recruitment of Polish citizens by the CIA (including BND collaboration) was concerned.

Selecting potential individuals for recruitment is connected with general knowledge about skills and functions performed in the country. Hence, the analyses place a lot of emphasis on foreign trips, especially ones made by scientific and technical workers as well as persons related to state-owned establishments engaging in trade with western countries. In the same risk group reckoned were the Polish citizens who were diplomats and diplomatic post employees, as well as international organisation employees, e.g. B. Walewski. It can be concluded that that was the target group on the radar of the US intelligence services in the 1970s and 1980s. There is no doubt that the Polish services were in no position to effectively counteract the so-called spontaneous forms of spying which consisted in Polish citizens initiating relations with foreign intelligence services, all the more so because the main motivation for such activity was money.

\section{(2) Second question conclusions}

The US intelligence areas of interest in the period in question changed mainly on account of the political situation in Poland. The rising significance of the anti-communist opposition led to the increase in the significance of the relations between the American services and its representatives and institutions supporting the opposition, e.g. the Catho- 
lic Church. Still, the main areas of interest for the US intelligence were concerned with obtaining information on: (1) the social, political and economic situation in Poland and the whole of the Eastern Bloc, (2) military and non-military technologies, (3) work on new military and non-military technologies, (4) research in the fields of life sciences and physics (particularly nuclear technologies and other technologies that might be even indirectly related to production of weapons of mass destruction), (5) the workings of the military, (6) the workings of the uniformed services and special services, (7) the military potential of Poland and the whole of the Eastern Bloc. The development of computer technologies brought about increased interest in this sphere and recruitment of persons involved in it.

\section{(3) Conclusions concerned with the critical analysis of the source material and doc- umentation}

Given the documentation produced by the Polish intelligence services and other institutions involved with state security, attention should be drawn to: (1) the kind of language they use, (2) the kind of persuasiveness they employ, and (3) the kind of indirect goals they espouse. The documents generated by the individual services, which described threat of espionage posed by the US intelligence services, use a special kind of nomenclature. First and foremost, use is made of expressions characteristic of these services and the specificity of their activity, but also of expressions aimed to highlight the significance of the identified threat. This kind of communication results in the creation of a special kind of persuasion intended to impact the recipient; there is also a special kind of selfpersuasiveness. For instance, ordinary behaviour related to the activity of diplomats in democratic states is presented by the Polish services - in the period under analysis - as manifestations of espionage. Hence, it must be assumed that many occurrences related to social communication processes might be presented as a kind of espionage or quasiespionage, which is peculiar to special services in non-democratic countries. This type of documentation (including graduation papers written by intelligence service officers at ministerial schools) is geared towards securing support from political decision-makers, serve to corroborate the effectiveness of intelligence services' activity and create awareness of threats to security in a variety of recipients, which is the effect that may be particularly desired by political decision-makers.

\section{Bibliography}

Act of 5 April 1955 on the transfer of jurisdiction over criminal cases of natural persons, officials of public security authorities, Civic Militia and Prison Service from military courts to common courts, Journal of Laws 1955 no. 15 item 83.

Act of 19 April 1969 Criminal Code, Journal of Laws 1969 no. 13 item 94.

Affet J. (1978), Wroga działalność niektórych pracowników dyplomatycznych ambasady USA w Warszawie, Legionowo.

An analysis concerned with the individuals contacting the US Consulate in Poznan in 1985 (1986), in: “ARETE” Premises Case, Institute of National Remembrance: Ref. no. Po/00/3/812/2.

An Analysis by the Provincial Office of Internal Affairs in Poznan concerned with the US Consulate in Poznań (1987), Document ref. no. CF-0289/87/KS. 
Andrejew I. (1973), Kodeks karny. Krótki komentarz, PWN, Warszawa.

Andrejew I., Pławski S. (1953), Prawo karne. Część szczególna, UW, Warszawa.

Andrejew I., Sawicki J. (1949), Istota przestęstwa w Polsce Ludowej. Kilka uwag z zakresu teorii prawa karnego, Ministerstwo Sprawiedliwości, Warszawa.

Austin J. L. (1962), Sense and Sensibilia, Oxford University Press, Oxford.

Austin J. L. (1993), Mówienie i poznawanie, PWN, Warszawa.

Bafia J., Hochberg L., Siewierski M. (eds.) (1965), Ustawy karne PRL. Komentarz, PW, Warszawa.

Bafia J., Mioduski K., Siewierski M. (1971), Kodeks krany. Komentarz, Wydawnictwo Prawnicze, Warszawa.

Belarus - Expulsion of diplomats (1997), “AP ARCHIVE”, 27.03.1997, http://www.aparchive.com/ metadata/youtube/984551d50af0cc4f8c94030bd68736d5, 20.12.2017.

Białowąs W. (1980), Psychologiczne motywy szpiegostwa, MSW, Warszawa.

Bronisławski J. (1974), Szpiegostwo, wywiad, paragrafy, MON, Warszawa.

Brzechczyn K. (2006), Między nauka a literatura, czyli debata nad statusem historii. Próba parafrazy, "Historyka. Studia Metodologiczne", vol. 36.

Brzechczyn K. (2012), Problem wiarygodności teczek i opartej na nich narracji historycznej. Kilka uwag metodologicznych, "Pamięć i Sprawiedliwość. Pismo Instytutu Pamięci Narodowej”, vol. 20 , no. 2 .

Brzechczyn K. (2013), Recepcja sporów pomiędzy pozytywizmem a narratywizmem w polskiej filozofii historii, "Ruch Filozoficzny", vol. LXX, no. 3.

A Catalogue of Persons Convicted for Espionage in Poland in the Period 1944-1984 (1986), Ministry of Internal Affairs, Warsaw.

Chybiński O., Gutekunst W., Świda W. (1971), Prawo karne. Część szczególna, PWN, Warszawa.

Ciecholewski L. (1984), Espionage in the light of the regulations of the criminal code and the study of the preparatory proceedings conducted by the Investigation Office of the Ministry of the Interior in 1979-1982 (graduation thesis), Ministry of the Interior Military Academy, Legionowo.

Decree of 13 June 1946 on particularly dangerous crimes in the period of the reconstruction of the State, Journal of Laws 1946 no. 30 item 192.

Decree of 26 October 1949 on the protection of state and official secrets, Journal of Laws 1949 no. 55 item 437.

A description of the foreign diplomatic personnel of the US Consulate in Poznan (1984), in: "ARETE" Premises Case, Institute of National Remembrance: Ref. no. Po/00/3/812/1.

Diehl J. (1987), Poles Charge U.S. Diplomat Spied, Claim Film is Proof, "The Washington Post", 23.04.1987, https://www.washingtonpost.com/archive/politics/1987/04/23/poles-chargeus-diplomat-spied-claim-film-is-proof/d5152495-4baf-439e-9f85-512fbabd7db8/?utm _ term $=.9905343 \mathrm{fd} 485,18.12 .2017$.

Bułhak W., Pleskot P. (2014), Szpiedzy PRL-u, Znak, Kraków.

Hilchey T. (1997), Joseph J. Loferski, Pioneer in Development of Solar Cells, Dies at 71, "The New York Times", 23.01.1997, http://www.nytimes.com/1997/01/23/us/joseph-j-loferski-pioneerin-development-of-solar-cells-dies-at-71.html, 20.12.2017.

Hoc S. (1985), Zagadnienia odpowiedzialności karnej za szpiegostwo, Akademia Spraw Wewnętrznych, Warszawa.

Informacja dyrektora Departamentu II MSW na temat nowych elementów w działalności amerykańskiej rezydentury wywiadowczej w Polsce z 24 lutego 1988 (1988), document published in: P. Pleskot (2013b), Dyplomata, czyli szpieg? Część II, IPN, Warszawa, pp. 607-615.

Information on the activity of the US Consulate in Poznan in 1979, Document ref. no. CF-002287/ $80 / \mathrm{ks}$. 
Information on the activity of the US Consulate in Poznan in 1985 (1986), in: “ARETE” Premises Case, Institute of National Remembrance: Ref. no. Po/00/3/812/2.

Information on the activity of the US intelligence services in the spheres of science, technology and invention in Poland (1988), in: "ARETE” Premises Case, Institute of National Remembrance: Ref. no. Po/00/3/812/2.

Information on the preventive activity of the US intelligence services towards American scholars (1984), in: Dossier no. 34 on the intelligence situation in 1983-1986, Institute of National Remembrance: Ref. no. BU 2602/19999.

Information on the penetrative-explorative activity of the US diplomats oriented towards gathering knowledge about the economic situation in Poland (1986), in: “ARETE” Premises Case, Institute of National Remembrance: Ref. no. Po/00/3/812/2.

Information on the relations between the US diplomats accredited to the Polish People's Republic and representatives of the opposition and the underground movement in 1983 (1984), in: "ARETE" Premises Case, Institute of National Remembrance: Ref. no. Po/00/3/812/1.

Instruction no. 0023 on the operational protection of the members of the US post resident spies along with the current list of resident operatives (1983), in: “ARETE” Premises Case, Institute of National Remembrance: Ref. no. Po/00/3/812/1.

Kaufman M. T. (1987), Warsaw Accuses U.S. Aide of Spying, “The New York Times”, 23.04.1987, http:// www.nytimes.com/1987/04/23/world/warsaw-accuses-us-aide-of-spying.html, 20.12.2017.

Komorowski decorates outgoing US ambassador Mull (2015), "Polish Radio", 08.07.2015, http://www. thenews.p1/1/10/Artykul/212948,Komorowski-decorates-outgoing-US-ambassador-Mull, 18.12.2017.20.

Kubala W. (1975), Sporne zagadnienia szpiegostwa, „Zeszyty Naukowe ASW”, no. 10.

Levinson S. C. (2010), Pragmatyka, Państwowe Wydawnictwo Naukowe, Warszawa.

A list of the members of the US post resident station (1983), in: “ARETE” Premises Case, Institute of National Remembrance: Ref. no. Po/00/3/812/1.

Lubaszewski M. (1989), Espionage in economy as a crucial link for gathering intelligence by enemy intelligence services (graduation thesis), Ministry of the Interior Military School, Legionowo.

Majkrzak W. (1990), The crime of espionage from the aspect of the cases run by the Provincial Office of Internal Affairs - Gdan'sk in 1975-1986 (graduation thesis), Academy of Internal Affairs, Legionowo.

Materials from the conference on the methodology of investigating espionage (1988), Department of Training and Professional Development at the Ministry of the Interior, Warszawa.

McLeod J. (2010), David Dastych Dead at 69, “CANADA FREE PRESS”, 12.09.2010, http://canadafreepress.com/article/david-dastych-dead-at-69, 20.12.2017.

Mir H. (2008), Nuclear proliferation cannot be controlled now, "The Daily Star", 30.01.2008, http:// www.thedailystar.net/news-detail-21222, 19.12.2017.

Muszyński J. (1971), Przestępstwo zdrady ojczyzny w nowym kodeksie karnym PRL, „Państwo i Prawo", no. 1.

Muszyński J. (1972), Przestępstwa przeciwko podstawowym interesom politycznym i gospodarczym PRL w kodeksie karnym z 1969 r., „Ruch Prawniczy, Ekonomiczny i Socjologiczny”, no. 2.

Piecuch H. (1996), Akcje specjalne, AW CB, Warszawa.

Pikulski S. (1980), Sporne zagadnienia w wyktadni unormowania przestępstwa szpiegostwa w kodeksie karnym PRL z 1969 r., „Wojskowy Przegląd Prawniczy”, no. 1.

Pikulski S. (1987), Przestępstwo szpiegostwa w teorii i w praktyce, MSW, Warszawa.

Pleskot P. (2013a), Dyplomata, czyli szpieg? część I, IPN, Warszawa.

Pleskot P. (2013b), Dyplomata, czyli szpieg?, część II, IPN, Warszawa. 
Poland Accuses U.S. Diplomat of Spying (1987), “The Los Angeles Times”, 23.04.1987, http://articles. latimes.com/1987-04-23/news/mn-757_1_diplomatic-immunity, 20.12.2017.

Polish Films of an American Shown as Evidence of Spying (1986), “The New York Times”, 21.06.1986, http://www.nytimes.com/1986/06/21/world/polish-films-of-an-american-shown-as-evidenceof-spying.html, 20.12.2017.

Rosicki R. (2016), Espionage against Poland in the Documents and Analyses of the Polish Special Services (1944-1989) - as Illustrated by the Intelligence Activities of the USA, "Środkowoeuropejskie Studia Polityczne", no. 1.

Sabik R. (1988), The crime of espionage as exemplified by the cases resolved by the Investigation Office at the Ministry of the Interior in 1976-1986 (graduation thesis), Ministry of the Interior Military School, Legionowo.

Siewierski M. (1958), Kodeks karny i prawo wykroczeń. Komentarz, PW, Warszawa.

Sroka A. (1988), The current state security threats posed by western intelligence services, in: Materials from the conference on the methodology of investigating espionage, Department of Training and Professional Development at the Ministry of the Interior, Warszawa.

Stawiarski S. (2007), Bez litości, Onet.pl, http://wiadomosci.onet.pl/kiosk/bez-litosci/gyzr9, 19.12.2017.

Supreme Court Resolution of 12 December 1973 (U 2/73).

Supreme Court Verdict of 29 July 1977 (Rs 8/77).

Supreme Court Verdict of 17 August 1979 (Rs 4/79).

Świda W. (1978), Prawo karne, PWN, Warszawa.

U.S. Diplomat Quits Poland After Accusation of Spying: Caught While Meeting Contact, Warsaw Says (1987), "The Los Angeles Times", 22.04.1987, http://articles.latimes.com/1987-04-22/news/ mn-363_1_poland-today, 20.12.2017.

Wierzbianski B. (ed.) (1996), Who's Who in Polish America, Bicentennial Publishing Corporation, New York.

Wojciechowska J. (1975), Zdrada ojczyzny w polskim prawie karnym na tle porównawczym, Ossolineum, Wrocław-Warszawa-Kraków-Gdańsk.

Yuenger J. (1986), U.S. Plots Terror, Poland Says, “Chicago Tribune”, 25.06.1986, http://articles.chicagotribune.com/1986-06-25/news/8602150346_1_anti-polish-pozoga-solidarity-movement, 20.12.2017.

Zacharski M. (2009), Nazywam się Zacharski. Marian Zacharski. Wbrew regułom, Zysk i S-ka, Poznań.

\section{Szpiegostwo USA wobec Polski w okresie 1970-1989}

\section{Streszczenie}

Zakres przedmiotowy problemu badawczego, prezentowanego w tekście, obejmuje wybrane kwestie dotyczące działalności szpiegowskiej USA wobec Polski w okresie od 1970 do 1989 roku. Głównym celem tekstu jest prezentacja stanu wiedzy i sposobu myślenia polskich służb specjalnych na temat zagrożeń wynikających z działalności wywiadowczej USA. W celu uszczegółowienia problemu badawczego zaprezentowano następujące pytania badawcze: 1) Jaki był zakres rozpoznania zagrożenia działalnościa wywiadowczq USA przez polskie stużby specjalne w okresie 1970-1989? 2) Jakie kierunki zainteresowań w działalności wywiadowczej USA przeciw Polsce dominowały w okresie 1970-1989?

W tekście skupiono się na: 1) ogólnej charakterystyce działalności szpiegowskiej w Polsce (uwzględniono zarówno aspekty ilościowe zjawiska, jak i aspekty prawne), 2) kierunkach zainteresowań wywiadu USA w Polsce (uwzględniono zarówno działalność placówek dyplomatycznych USA, 
jak i wybrane sfery, będące w zainteresowaniu wywiadu USA, np. gospodarkę, przemysł i środowisko naukowe).

W tekście wykorzystano materiały i dokumenty wytworzone przez Ministerstwo Spraw Wewnętrznych i Ministerstwo Obrony (oraz instytucje im podległe, np. służby specjalne) z lat 1970-1989. Do krytycznego opracowania materiałów i dokumentów wykorzystano w sposób swobodny teorię aktów mowy autorstwa J. L. Austin'a. Ponadto w zakresie analizy problematyki prawnej szpiegostwa wykorzystano wykładnię dogmatyczną prawa.

Słowa kluczowe: szpiegostwo, działalność szpiegowska, działalność wywiadowcza, działalność kontrwywiadowcza, szpiegostwo USA, służby specjalne, bezpieczeństwo państwa, bezpieczeństwo informacyjne 
